\title{
交流電圧の長時間印加における真空ギャップ絶縁破壊特性と その放電コンディショニングによる改善
}

\author{
正 員 佐藤 伸治* 正 員 小山 健一* \\ 正 員 系谷 孝行** 非会員 宮本 聖一 $* *$
}

\section{Breakdown Characteristics of Vacuum Gaps under Continuous AC Voltage Application and their Improvements by means of Discharge Conditionings \\ Shinji Sato*, Member, Kenichi Koyama*, Member,

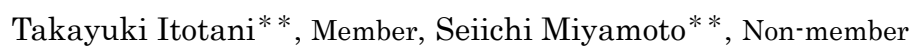

In order to identify the long span reliability of vacuum gap insulation under continuous $\mathrm{AC}$ voltage application, characteristics of breakdown strength versus breakdown time (long time E-t characteristics) were measured for a uniform and a non-uniform field gap. The breakdown strength of these gaps before the discharge conditioning treatments did not depend on breakdown time. However, after the discharge conditioning treatments, the breakdown strength became describable as an experimental formula $\mathrm{E}=\mathrm{A} \cdot \mathrm{t}^{-1 / \mathrm{n}}$. The value of drop index (life index) $n$ in the formula was a maximum of 75 for the uniform field gap, while a maximum of 25 for the non-uniform field gap. In addition, with repeating the discharge conditioning treatment, the long time E- $t$ characteristics of both gaps shifted to higher electric field. In particular, the value of $n$ for the uniform field gap became larger. Breakdown modes (failure modes) of these gaps before and after the discharge conditioning treatments, evaluated by the value of shape parameter $m$ in Weibull probability distribution function, were classified into decreasing failure rate mode and constant failure rate mode, respectively.

キーワード : 真空, 絶縁破壊, 長時間 $\mathrm{E}-\mathrm{t}$ 特性, 放電コンディショニング

Keywords : vacuum, breakdown, long time E-t characteristic, discharge conditioning

\section{1. はじめに}

$\mathrm{SF}_{6}$ ガスが温室効果ガスに指定されたことを背景に, 開閉 装置では真空絶縁の適用範囲が拡大している。真空絶縁は 真空遮断器の接点間絶縁だけでなく, 断路器や接地開閉器 の接点間や対地間絶縁にも適用され始めている(1) (3)。これ らの新たな真空絶縁では，交流電圧の連続印加時間が真空 遮断器の接点間絶縁よりも長くなる。すなわち真空遮断器 接点は常時閉の状態で運用されることが多く，その場合電 流遮断のため接点を開極した後に絶縁が必要になる。これ

\footnotetext{
三菱電機（株）先端技術総合研究所

言661-8661 尼崎市塚口本町 8-1-1

Advanced Technology R\&D Center, Mitsubishi Electric Corporation

8-1-1, Tsukaguchi-honmachi, Amagasaki 661-8661

** 三菱電機 (株) 受配電システム事業所

干763-8516 丸亀市蓬莱町8 番地

Power Distribution Systems Center, Mitsubishi Electric

Corporation

8, Horai-cho, Marugame 763-8516
}

に対し，対地間絶縁および常時開極状態で用いられる接地 開閉器の接点間絶縁では, その機能上, 長期間の連続的な 絶縁が必要になる。このような背景から, 真空絶縁の長期 信頼性に対する検討が必要になっている。

真空絶縁の長期信頼性を検討するには，交流課電時間に 対する破壊電圧または破壊電界の特性(本論文では長時間 $\mathrm{V}-\mathrm{t}$ 特性または長時間 E- $\mathrm{t}$ 特性と呼び，印加電圧波形の影響 検討のために測定する $\mu \mathrm{s} \sim \mathrm{ms}$ 領域の V-t, E-t 特性と区別 した)を取得し, その特性に基づいて長時間課電時の破壊電 圧を見積もる必要がある。しかしこの点を検討した報告は 少ない。長時間課電に伴う破壊電圧の低下は知られている が(4) (6), その低下割合を表し絶縁裕度見積もりに重要な垂 下係数(または寿命係数)の值は不明確である。実用面では, 短時間破壊特性の向上に効果がある放電コンディショニン グの，長時間破壊特性に対する効果の検討も必要と思われ る。さらに, 長時間課電に伴う破壊電圧の低下が, 電極表 面状態の劣化に起因するかの検討も必要である。これらに 
関する報告は見当たらない。

本研究では, 平等電界と不平等電界の真空ギャップにつ いて最長 220 時間までの長時間 E-t 特性を測定し, 両ギヤ ップの垂下係数を明確にした。また，放電コンディショニ ングの長時間破壊特性に対する効果を, 放電コンディショ ニング回数による垂下係数の変化から検討した。さらに, 長時間課電時の電極表面状態の劣化について検討するた め, 長時間 E-t 特性の測定データをワイブル統計処理し, 同 処理から得られる形状パラメータ $\mathrm{m}$ の值から長時間課電時 の破壊モードを調べた。

\section{2. 実験方法}

〈2·1〉 供試ギャップ 長時間 $\mathrm{E}-\mathrm{t}$ 特性の測定には 2 種類のギャップを用いた。ひとつは図 1(a)に示した平板対 平板ギャップである。電極の材質は無酸素銅，表面の中心 線平均粗さ $(\mathrm{Ra})$ は約 $1.0 \mu \mathrm{m}$ である。もうひとつは, 同図 (b)(c)のように銅䈃を重祆合わせた電極に, 平板電極を対向 させた銅箔対平板ギャップである。このギャップは銅管を 重ね合わせた構造の可とう導体が真空中に配置された場合 を想定しており, 極端な不平等電界下での長時間 E-t 特性取 得を目的としている。ギャップの銅箔側は厚さ $0.2 \mathrm{~mm}$ の銅 䇴を 10 枚重ねあわせている。同図(c) のように銅䈃の間に 隙間ができるようにたわませ, 銅䇤抑え板(銅製)にボルトで 固定した。銅筸の端部には丸め処理は行っていない。どち らのギャップも, 内部圧力約 $10^{-4} \mathrm{~Pa}$ のベローズ付きセラミ ック管に封入されている。

〈2·2〉 測定回路 図 2 に測定回路を示す。セラミッ ク管は絶縁架台上にセットされ, 手動スライダックで調節 された $60 \mathrm{~Hz}$ 交流電圧を印加できる。測定回路の高圧側には 供試ギャップと直列に $50 \mathrm{k} \Omega$ の制限抵抗が挿入されている。 接地線には放電電流測定用の高周波 $\mathrm{CT}$ が取り付けられ, $\mathrm{CT}$ 出力は $50 \Omega \mathrm{BNC}$ ケーブルによりトランジェントレコー ダに入力される。トランジェントレコーダはトリガレベル を超える信号が入力された場合に自動的に検出波形と検出 時刻を記録できる。なお，一連の測定の前に大気中でコロ ナ放電が発生していないことを確認している。

〈2·3〉 長時間 E-t 特性の測定方法 真空ギャップに 一定交流電界をある適切な值で印加すると， ある長さの時 間遅れ後に絶縁破壊が発生する。そのときに流れる電流が 抵抗などによって小さく制限されていれば直ちに消弧さ れ, ギャップ間の絶縁が回復する。その後, ある時間遅れ 後に再び絶縁破壊が発生し, 同様に直ちに絶縁回復する。 このように破壊と消弧を繰り返させ，破壊時の電流を高周 波 CT で検出すれば, ある破壊から次の破壊までの時間間隔 $\mathrm{T} 1$ ， T2，T3，・が測定できる。この時間間隔 $\mathrm{T}$ を破壊ま での時間とする。印加電界を変化させて同様の測定を行い, 印加電界と破壊までの時間の関係をグラフ化すれば，長時 間 $\mathrm{E}-\mathrm{t}$ 特性を得ることができる。

上記考え方に基づき次の手順で長時間 $\mathrm{E}-\mathrm{t}$ 特性を測定し た。

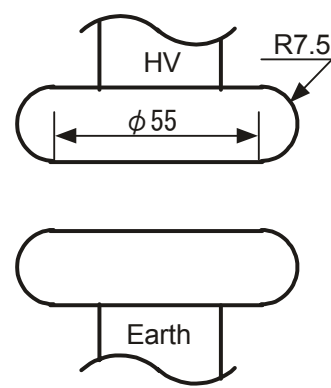

(a)Plate-to-plate gap

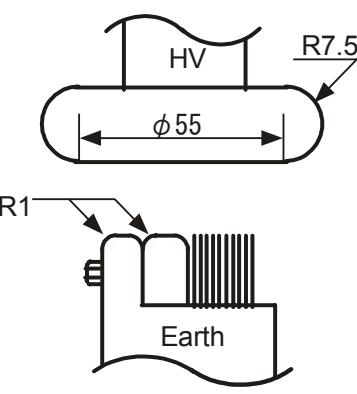

(b)Foils-to-plate gap

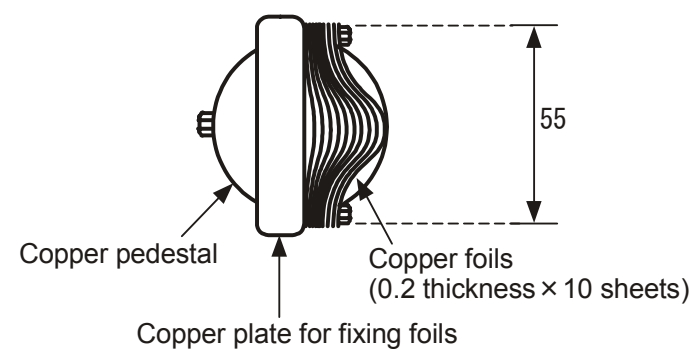

(c)Bird's-eye view of foils-to-plate gap

図 1 長時間 E-t 特性の測定に用いた電極構成

Fig. 1. Electrode arrangements for measurements of long time E-t characteristics.

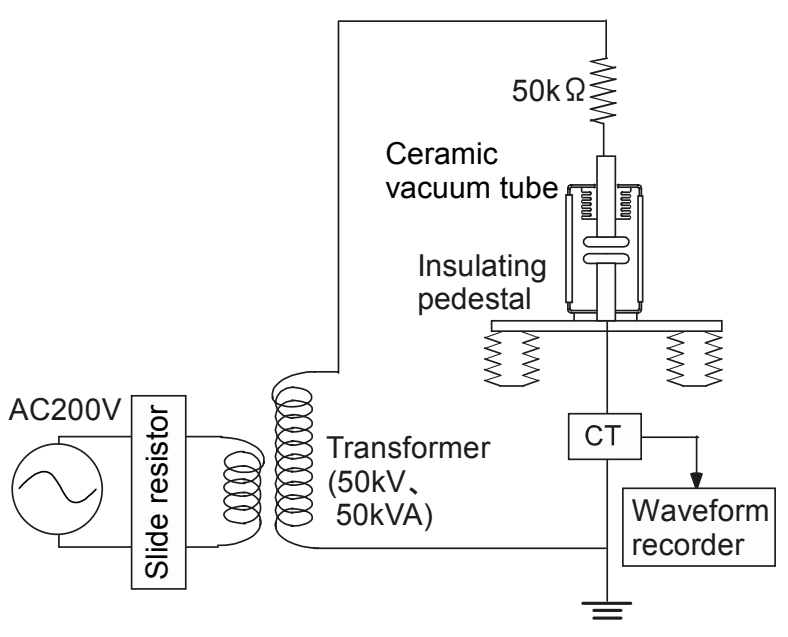

図 2 測定回路の概略

Fig. 2. Experimental circuit.

（1）放電コンディショニング前の予備的な長時間 E-t 特 性測定（平板対平板ギャップのみ）

（2）1 回目の放電コンディショニング（交流電圧 10 分 間)

（3） 1 回目の長時間 E-t 特性測定（1 回目の放電コンデ イショニング電界以下の範囲)

（4）２回目の放電コンディショニング $(1.15 / 3.8 \mathrm{~ms}$ 開閉 インパルス電圧。破壊回数 100 回以上)

（5） 2 回目の長時間 E-t 特性測定（2 回目の放電コンデ 


\section{イショニング電界以下の範囲）}

ここで，1，2 回目測定および予備測定では電界印加の大 小順は決めていない。また放電コンディショニング電圧は, 1 回目は最大 $65 \mathrm{kVrms}$ (85kVpeak), 2 回目は 90〜 $120 \mathrm{kV}$ として，2回目のほうが高くなるようにした。1 回目の放 電コンディショニングでは昇圧中に絶縁破壊が多発した。 設定電圧到達後も約 1 分間は破壊頻度が $5 \sim 10$ 秒に 1 回程 度発生したが，その後は減少した。

本研究のように，単一ギャップを繰り返し破壊させて得 たデータから破壊特性を検討寸る場合，ある時点で発生し た破壊がその次の破壊に影響を与えていないことが前提と なる。この点を確認するため, 図 3 に平板対平板ギャップ の長時間 E-t 特性における, 破壊までの時間と破壊番号の関 係の一例を示す。両者の間に何等かの相関関係が見出せる 場合，ある時刻の破壊がその次の破壊に影響を与えている 可能性がある。しかし，同図から破壊番号に対する破壊ま での時間の減少や増加は特に認められない。同様の結果が 他の測定条件でも確認された。設定電界への昇圧後破壊時 間の記録をこの結果から，ある時刻の破壊がそれ以降の破 壊に特に影響を与えていることはないと判断した。なお， 図 3 の傾向は放電コンディショニング前の予備測定でも, 印加電界を所定の值に設定してから 1 ～ 2 分経過すれば確 認することができた。

\section{3. 実験結果と検討}

\section{〈3·1〉 真空ギャップの長時間 E-t 特性における垂下係}

数本節ではまず，長期課電時の絶縁信頼性評価の上で 重要になる, 長時間 $\mathrm{E}-\mathrm{t}$ 特性の垂下係数を検討する。放電コ ンディショニング処理後の平板対平板，銅箔対平板ギャッ プの長時間 E-t 特性を図 4(a)(b)にそれぞれ示す。ここで, 両図の凡例中の $50 \%$ 破壊時間は各印加電界下での全データ のうちの $50 \%$ が破壊する時間のことで，後述のワイブルプ ロット処理により計算した。50\%破壊時間については，下

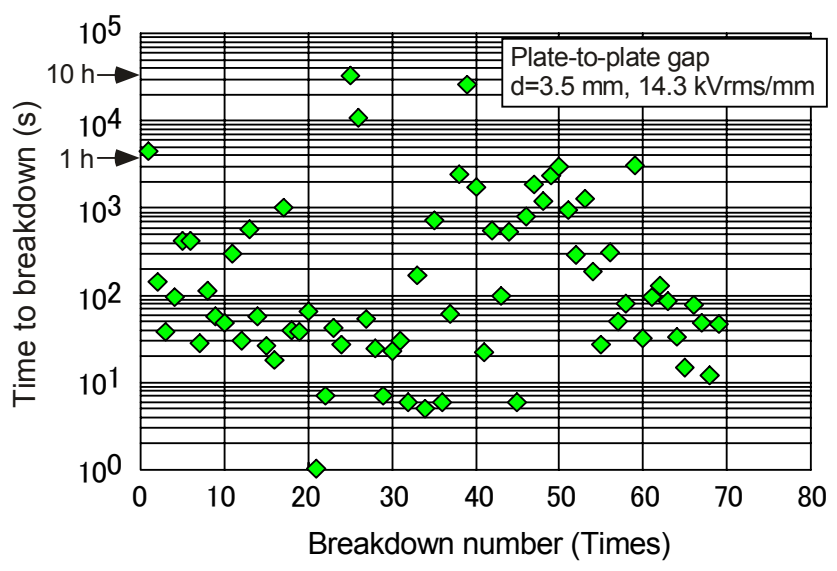

図 3 破壊までの時間と破壊番号の関係の一例

Fig. 3. An example of relationship between time to breakdown and breakdown number.
記の一般式(7)で表される最小自乗近似直線を図中に記入し た。

$$
\mathrm{E}=\mathrm{A} \cdot \mathrm{t}^{-1 / \mathrm{n}} \text {. }
$$

ただし, $\mathrm{A}$ は定数, $\mathrm{n}$ は垂下係数である。破壊電界は, 平板 対平板ギャップでは(電圧)/(ギャップ長)から計算した。銅䈃 対平板ギャップの銅䈃端部の電界は正確に計算できないの で, 電界解析ができる類似の形状(厚さ $1 \mathrm{~mm}$, 端部半径 $0.5 \mathrm{~mm}$ の丸め処理が行われた箔)における先端電界で表示 した。また, 電極表面上の絶縁破壊の発生箇所について, 真空チャンバ内で行った別の実験により確認している。そ の結果, 平板対平板ギャップでは電極の平坦部で, 銅箔対 平板ギャップでは銅箔の先端部に加え, 図 1(b)(c)中の銅箔 押さえ板や台座でも放電していることが分かっている。

図 4(a)(b)から，50\%破壊時間の最小自乗近似直線は負の 傾きを持っている。この近似直線から計算した垂下係数の 值を, $\mathrm{SF}_{6}$ ガス ${ }^{(7)}$ とマイカ/エポキシ複合絶縁系(8)における值 と共に表 1 に示す。同表には，真空ギャップと真空沿面ギ ヤップを対象とした, 他者による長時間 V-t 特性の垂下係数 も記した。なお，文献(4)には垂下係数が記載されていない ので著者らが計算した。

同表から, 真空ギャップの長時間 E-t 特性の垂下係数につ いて, 以下の 3 つの特徴を挙げることができる。第一番目 は, 垂下係数の值は小さい場合でも 20 台の前半となってい る点である。すなわち, 本研究における平板対平板ギャッ プの放電コンディショニング 1 回後の值は 22.3 , 銅䈃対平 板ギャップの測定 1,2 回目はどちらも約 25 である。文献 (5)の真空沿面ギャップでの值が 23 である点も含め, 真空絶 縁系では最小でも 20 以上の值が得られている。固体絶縁材 料では同表中のマイカIエポキシ複合絶縁系のように 20 以 下の場合が多く, 真空絶縁系の長時間 E-t 特性は固体絶縁材 料のそれよりも傾きが緩やかといえる。

第二番目の特徵は，平等電界ギャップでは放電コンディ ショニング処理を行うほど垂下係数が増大し, $\mathrm{SF}_{6}$ ガスギャ ップの值と同等になる点である。本研究の平板対平板ギャ ップの放電コンディショニング 2 回後では垂下係数は 74 で あり, 同 1 回後から大きく増加している。同表中の $\mathrm{SF}_{6}$ ガ スギャップでは, 異物の無い場合は 75 , 異物が存在する場 合は 38〜 62 である。したがって，十分な放電コンディショ ニング後の平等電界ギャップなら, $\mathrm{SF}_{6}$ ガスギャップと同様 の平坦な長時間 $\mathrm{E}-\mathrm{t}$ 特性が得られる。

第三番目の特徵は第二番目と関連するが，不平等電界ギ ヤップでは十分に放電コンディショニングを与えても, 平 等電界ギャップほど大きな值の垂下係数は得られない点で ある。不平等電界分布を含む真空絶縁系では，この点を考 慮した長時間課電に対する絶縁設計が必要である。

以上のように, 真空ギャップの長時間 $\mathrm{E}-\mathrm{t}$ 特性における垂 下係数は小さくても 20 台の前半で, 十分に放電コンディシ ヨニングを与えた後の平等電界ギャップでは最大 74 に達し た。これらの值は固体絶縁材料より大きく, 平等電界ギャ ップでは $\mathrm{SF}_{6}$ ガスギャップとほぼ同等である。 


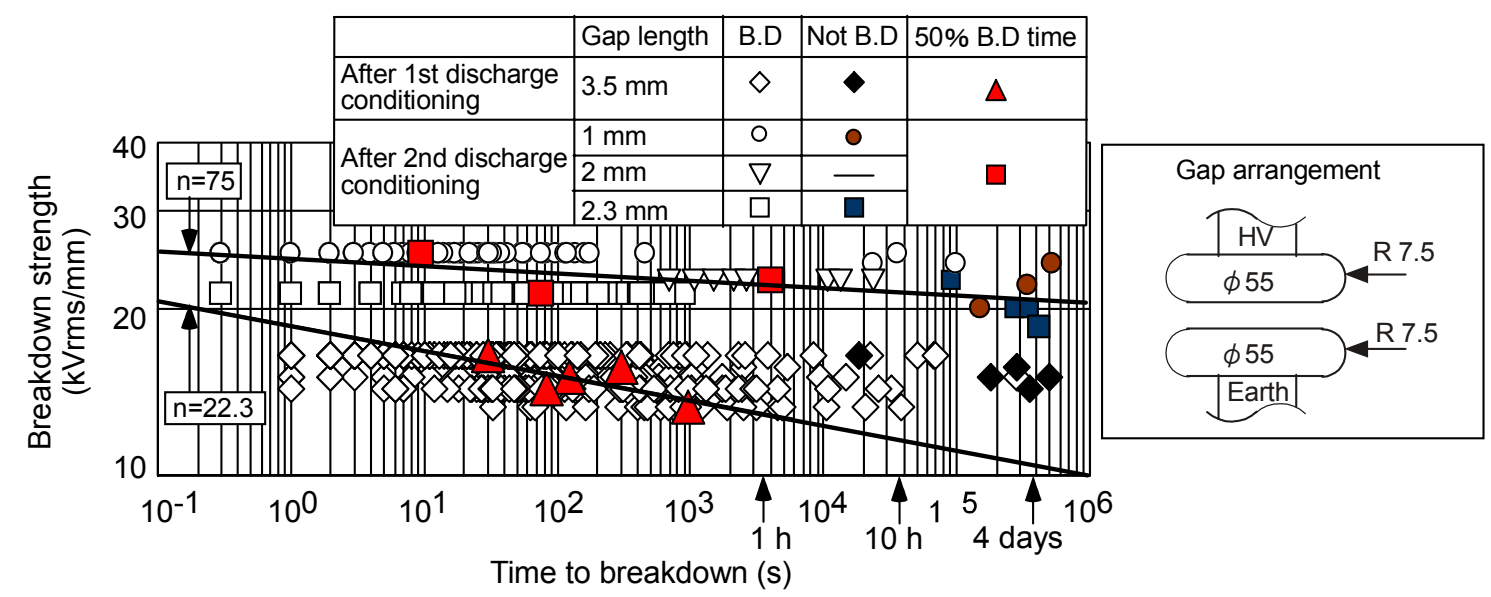

(a) Plate-to-pale gap

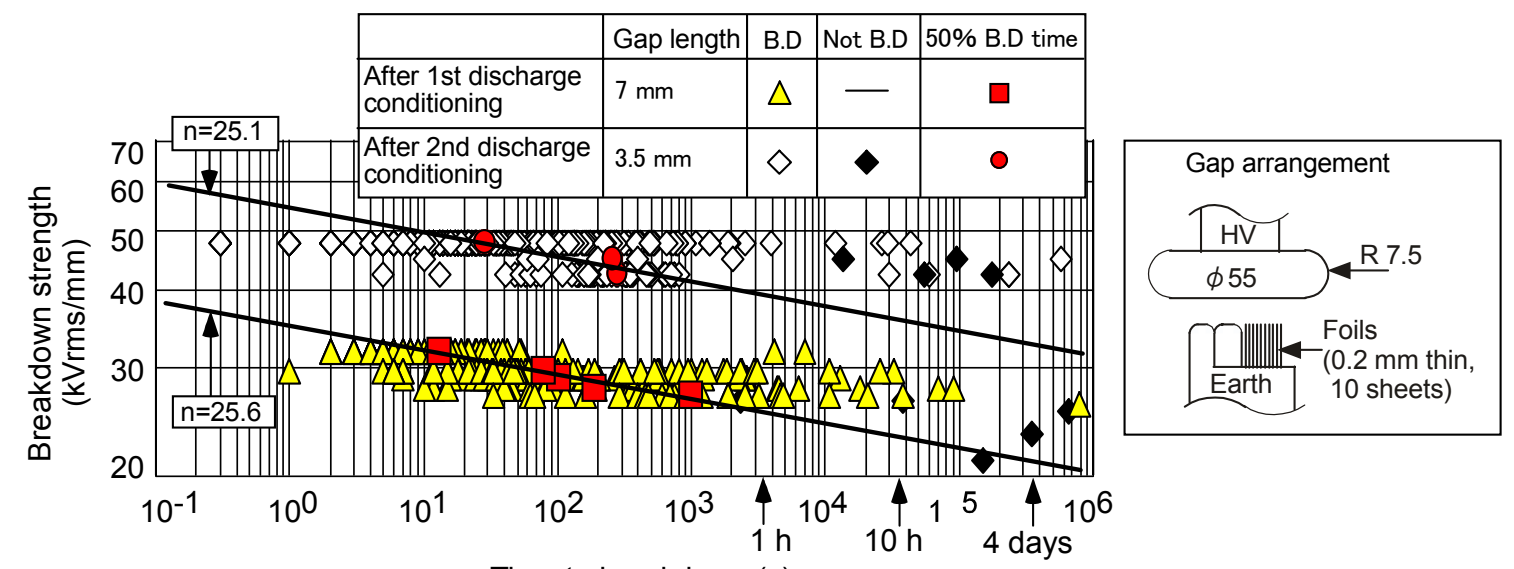

Time to breakdown (s)

(b) Foils-to-pale gap

図 4 真空ギャップの長時間 E-t 特性

Fig. 4. Long time E-t characteristics of vacuum gaps.

表 1 各種絶縁方式における長時間 $\mathrm{E}-\mathrm{t}(\mathrm{V}-\mathrm{t})$ 特性の垂下係数 $n$

Table 1. Drop index $n$ in long time E-t $(V-t)$ characteristics of insulation systems.

\begin{tabular}{|c|c|c|c|}
\hline & Measuring conditions & Drop index $n$ & $\begin{array}{l}\text { Longest time of voltage } \\
\text { application }\end{array}$ \\
\hline \multirow{3}{*}{ Vacuum gap } & $\begin{array}{l}\text { Plate-to-plate gap (this work) } \\
\text { (Copper, } \mathrm{d}=1-3.5 \mathrm{~mm} \text { ) }\end{array}$ & $\begin{array}{l}22.3 \text { (After AC discharge conditioning) } \\
75 \text { (After AC+Impulse discharge conditioning) }\end{array}$ & 28 hours \\
\hline & $\begin{array}{l}\text { Foils-to-plate gap (this work) } \\
\text { (Copper, } \mathrm{d}=3.5-7 \mathrm{~mm})\end{array}$ & $\begin{array}{l}25.6 \text { (After AC discharge conditioning) } \\
\text { 25.1(After AC+Impulse discharge conditioning) }\end{array}$ & 5 days \\
\hline & $\begin{array}{l}\text { Plate-to-plate }^{(4)} \\
\text { (Nickel, d=7.5 mm, DC) }\end{array}$ & 47.6 & 80 minutes \\
\hline $\begin{array}{l}\text { Insulator surface } \\
\text { in vacuum }\end{array}$ & $\begin{array}{l}\text { Electron beam irradiation toward a glass } \\
\text { plate }^{(5)} \quad(10 \mathrm{~mm} \text { long, DC })\end{array}$ & 23 & 200 minutes \\
\hline \multirow{2}{*}{$\mathrm{SF}_{6}$ gas } & With needle particles, 0.35 MPa.abs. ${ }^{(7)}$ & $38-62$ & 1.5 hours \\
\hline & Without particles, 0.3, 0.44 MPa.abs. ${ }^{(7)}$ & 74 & 100 hours \\
\hline Solid & Model mica/epoxy compound coil ${ }^{(8)}$ & $7-10$ & 14 months \\
\hline
\end{tabular}

〈3·2〉放電コンディショニングに伴う長時間 E-t 特性 の変化図 5 に, 平板対平板ギャップの放電コンディシ ヨニング処理前の長時間 E-t 特性を示す。同図より $50 \%$ 破 壊時間と破壊電界の間に明確な相関関係は見出せず, 前記
(1)式でのこの特性の近似はできない。本節では放電コンデ イショニングに伴う長時間 $\mathrm{E}-\mathrm{t}$ 特性の変化を検討するにあ たり，まず図 5 が(1)式で表現できない理由から検討する。 同図における電界の印加順序は 2.0, 5.0, 4.0, $4.4 \mathrm{kV} / \mathrm{mm}$ 


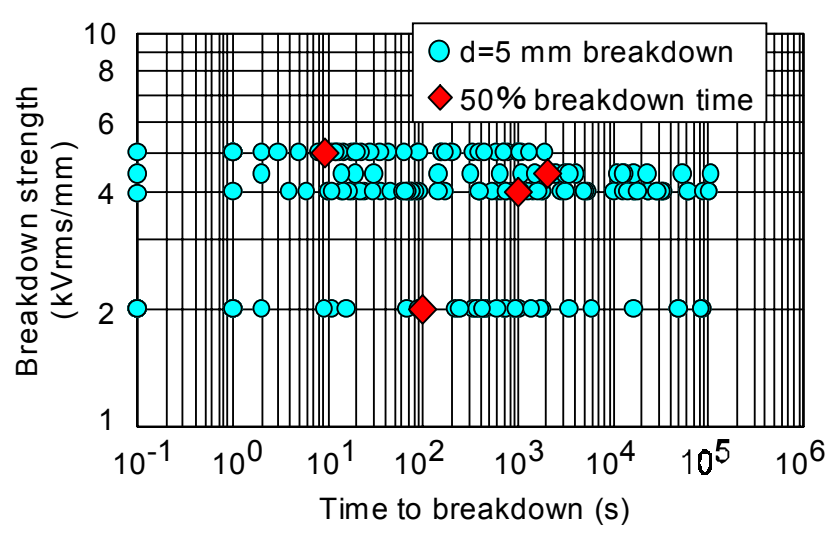

図 5 放電コンディショニング処理を行う前の平板対 平板ギャップの長時間 $\mathrm{E}-\mathrm{t}$ 特性

Fig. 5. Long time E-t characteristics of plate-to-plate gap before conducting the discharge conditioning treatment.

である。後者 3 つの電界だけで長時間 E-t 特性をプロット すると，ある程度時間依存性を持った特性とみなすことも できる。そこで, $2.0 \mathrm{kV} / \mathrm{mm}$ 印加を放電コンディショニン グ処理とみなすと，コンディショニング電界よりも長時間 E-t 特性の測定電界が高い場合は(1)式に従わないと考える ことができる。一方， $5.0 \mathrm{kV} / \mathrm{mm}$ 印加を同処理のひとつと みな寸と, 処理電界よりも測定電界が低い場合なら(1)式に 従うと考えることができる。

このことから図 5 全体で破壊電界と破壊時間の間に明確 な相関関係が見出せない理由は, ある印加電界での測定が その後の別電界での測定における放電コンディショニング 処理として作用している場合と，していない場合が混在し ているためと考えられる。言い換えると(1)式で表現可能な 長時間 $\mathrm{E}-\mathrm{t}$ 特性を得るには, その測定における最大電界より 高い電界で放電コンディショニングを行う必要がある。こ の点は図 4(a)(b)が全て放電コンディショニング電界よりも 低い範囲で測定されていることからも裏付けられる。長時 間 E-t 特性が(1)式で表現できれば破壊電界の低下量が予測 可能になり，この意味でギャップ間を運転電界よりも高電 界で放電コンディショニングすることが重要である。

このような長時間 E-t 特性の変化の原因には, 電極表面状 態の放電コンディショニングによる変化が挙げられる。放 電コンディショニング前の電極表面には吸蔵ガスや微小異 物が残留している(9)。これらが放電コンディショニングで除 去されると長時間 E-t 特性が(1)式で表現可能な形態に変化 すると考えられる。この電極表面状態の変化については次 節で検討する。

さらに図 4(a)(b)から，放電コンディショニング処理の回 数増加による長時間 $\mathrm{E}-\mathrm{t}$ 特性の変化については, 次のように 説明することができる。放電コンディショニング 2 回後の ほうが長時間 E-t 特性は高電界側にシフトし, 特に平等電界 ギャップでは垂下係数が増大している。2 回後のほうが 1 回後よりも破壊回数と総課電時間は増大し，コンディショ
ニング電圧も上昇しているので，2回後のほうが十分な放 電コンディショニングとみてよい。このように長時間課電 時の破壊電界の絶対值, および課電時間に対する破壊電界 の低下割合は，放電コンディショニング履歴に依存する。

以上をまとめると, 放電コンディショニング処理には次 の二つの効果がある。一つ目は長期課電時の破壊電界の低 下に予測を与えるという効果である。ただし，この効果は 長時間 E-t 特性の測定電界以上にコンディショニング電界 が高くなければ表れない。二つ目は，放電コンディショニ ング履歴に依存して長時間 E-t 特性は高電界側にシフトし, 特に平等電界ギャップでは同特性を平坦化させるという効 果である。この他, 放電コンディショニング効果は次節で 述べるように, ワイブルプロットの傾きから分類できる絶 縁破壊モードの変化にも表れる。

〈3.3〉長時間連続課電時の真空ギャップの絶縁破壊モ ード 本節では長時間 E-t 特性のデータをワイブルプロ ット処理し, 形状パラメータ $\mathrm{m}$ の值の大小から, 長時間連 続課電時の真空ギャップの破壊モードを検討する。(2)式に ワイブル分布関数 ${ }^{(10)}$ を示す。ここで, $\mathrm{f}$ は破壊確率, $\mathrm{t}$ は電 圧の印加時間, $\mathrm{t}_{0}$ は尺度パラメータ, $\mathrm{t}_{\min }$ は位置パラメータ, $\mathrm{m}$ は形状パラメータである。

$\mathrm{f}=1-\exp \left[-\left\{\left(\mathrm{t}-\mathrm{t}_{\min }\right) / \mathrm{t}_{0}\right\} \mathrm{m}\right]$

形状パラメータ $\mathrm{m}$ (以下 $\mathrm{m}$ ) はワイブルプロットにおける直 線の傾きであり，破壊までの時間のばらつきが大きいほど 小さくなる。また，この值の大小から破壊モードは以下の 3 種類に分類される。

$\mathrm{m}<1$ : 初期故障形破壊

$\mathrm{m}=1$ : 偶発故障形破壊

$\mathrm{m}>1:$ 経年劣化故障形破壊

以下， $\mathrm{m}$ の值の大小から長時間連続課電時の真空ギャップ の破壊モードを検討する。なお位置パラメータ $t_{\text {min }}$ は実験 結果からの算出が困難 $(10)$ なので，本論文では 0 とした。

図 6(a)に平板対平板ギャップの 1 回目の長時間 E-t 特性 に対するワイブルプロットを示す。また同図(b)に，同ギャ ップで放電コンディショニング前に測定した長時間 E-t 特 性に対する同プロットを示す。両図中には傾きが $1 （ \mathrm{~m}=1)$ の直線を点線で記入した。

図 6(a)(b)を比較すると, 破壊までの時閒がおよそ $10^{3} \mathrm{sec}$ 以下の範囲の $\mathrm{m}$ 值に違いがある。この違いを明確にするた め，上記範囲で特に直線性が高い，累積破壊確率 10〜80\% の範囲で最小自乗近似を行い，それぞれm值を計算した。 $\mathrm{m}$ 值の計算結果を表 2 に示す。同表から $\mathrm{m}$ 值は放電コンデ イショニング前は $0.2 \sim 0.3$ であるが，その後は $0.6 \sim 0.9$ に 増加している。このことから破壊までの時間のばらつきは, 放電コンディショニングにより小さくなることが分かる。

放電コンディショニングによる $\mathrm{m}$ 值の変化をさらに検討 するため, 図 7 に平板対平板, 銅䈃対平板ギャップ両方の $\mathrm{m}$ 值の放電コンディショニング回数に対する変化を示す。 同図から, $\mathrm{m}$ 值は放電コンディショニング前から 1 回後で は増加寸るが，1回後から 2 回後では大きな変化はない。ま 


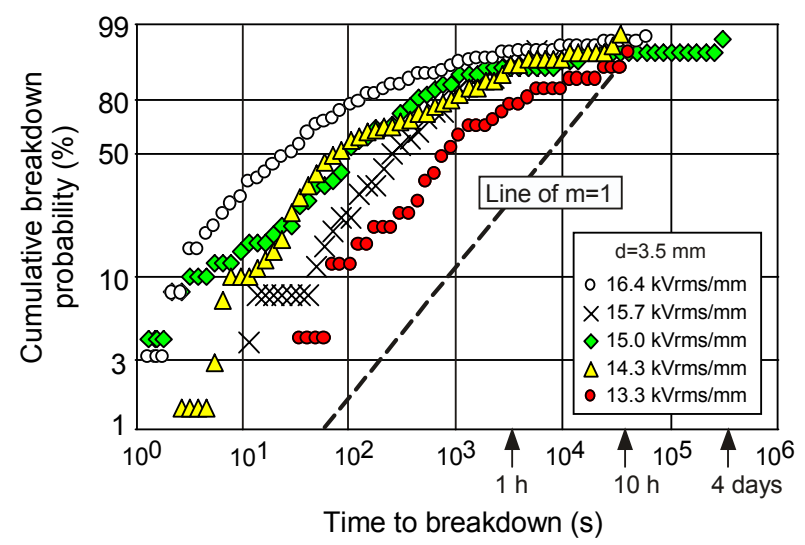

(a) After discharge conditioning (using AC voltage)

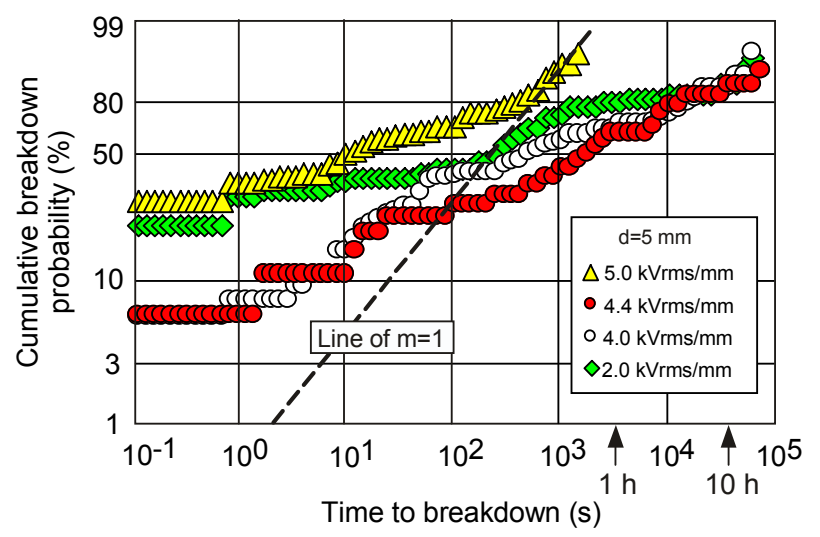

(b) Before discharge conditioning

図 6 破壊までの時間についてのワイブルプロット

Fig. 6. Weibull plots for time to breakdown.

た， 1,2 回後の $\mathrm{m}$ 值は最大約 1.4 に達してはいるが， 2.0 や 3.0 というように大きく 1.0 から離れていない。

この $\mathrm{m}$ の変動は, 放電コンディショニング処理による電 極表面状態の変化と対応させると, 以下のように考えられ る。すなわち，放電コンディショニング未実施の場合，電 極表面には吸着ガスや微小異物が残留し，鋭い形状の微小 突起が存在する場合もある(9)。これらの影響により真空ギャ ップ本来の絶縁性能が発揮されにくい。これは課電前から 絶縁破壊を引き起こす因子が絶縁システムに内在している という，初期故障形破壊と解釈することができる。このた め $\mathrm{m}$ が 1.0 よりも小さくなったと考えられる。

放電コンディショニングによって吸着ガス, 微小異物が 除去され, 微小突起が滑らかになると考えられているが(9), これらは初期故障形破壊を引き起こす因子の除去にあた る。その結果, 真空ギャップ本来の絶縁性能が表れ始め, 破壊電界が上昇する。これは放電コンディショニングによ り破壊モードが初期故障形から別のモードへと移行したと 解釈できる。放電コンディショニング 1 回後に $\mathrm{m}$ が上昇し たのはこのためと考えられる。 $\mathrm{m}$ の值は 1.0 に近づいている ことから, 移行後の破壊モードは偶発故障形と考えられる。
表 2 図6(a)(b)のワイブルプロットにおける

$$
\text { 形状パラメータ } m
$$

Table 2. Shape parameter $m$ of Weibull plots in Fig.6(a)(b).

\begin{tabular}{|c|c|c|c|}
\hline \multicolumn{2}{|c|}{$\begin{array}{c}\text { After discharge } \\
\text { conditioning }\end{array}$} & \multicolumn{2}{c|}{$\begin{array}{c}\text { Before discharge } \\
\text { conditioning }\end{array}$} \\
\hline $\begin{array}{c}\text { Electric field } \\
(\mathrm{kVrms} / \mathrm{mm})\end{array}$ & $m$ & $\begin{array}{c}\text { Electric field } \\
(\mathrm{kVrms} / \mathrm{mm})\end{array}$ & $m$ \\
\hline 13.3 & 0.82 & 2.0 & 0.21 \\
\hline 14.3 & 0.89 & 4.0 & 0.35 \\
\hline 15.0 & 0.58 & 4.4 & 0.33 \\
\hline 15.7 & 0.91 & 5.0 & 0.25 \\
\hline 16.4 & 0.67 & & \\
\hline
\end{tabular}

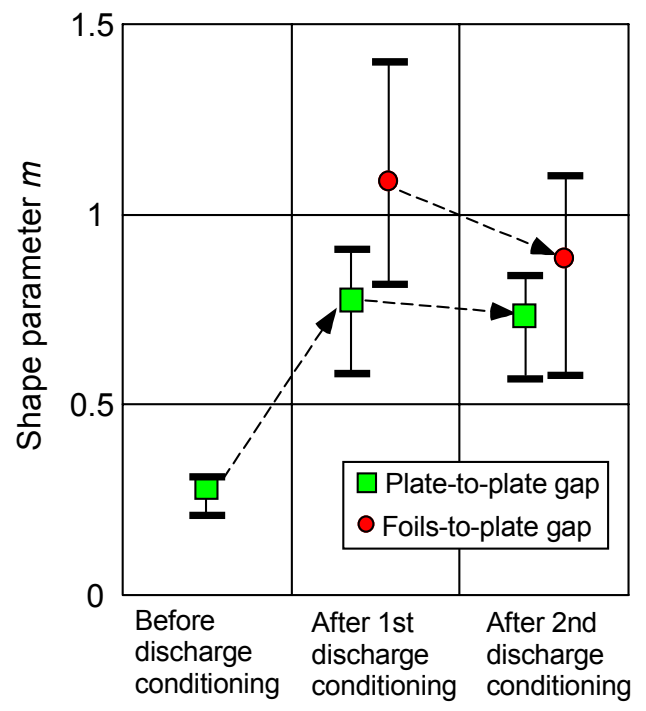

図 7 ワイブルプロット形状パラメータ $\mathrm{m}$ の 放電コンディショニングによる変化

Fig. 7. Variation of shape parameter $m$ in Weibull distribution formula with discharge conditionings.

そして, 放電コンディショニング 2 回後でも $\mathrm{m}$ の值が 1.0 に近い点から，ある程度放電コンディショニングを与えた 後は破壊モードは偶発故障形に保たれ, 経年劣化形破壊に は変化しないと考えられる。ここで, 文献(9)のマイカ/エポ キシ複合絶縁系では本研究と同様に $\mathrm{m}$ を調べているが, そ の值は $1.2 \sim 5.27$ の範囲である。この点は同絶縁系では部分 放電による経年劣化形破壊が発生することと対応してい る。真空ギャップでこのような大きな值の $\mathrm{m}$ がほとんど見 出されなかったことから, 長時間の連続的な電圧印加によ り真空ギャップが絶縁破壊しやすい状態に劣化することは ないと考えられる。

以上, 交流電圧の連続印加における真空ギャップでは, 放電コンディショニング未実施の場合は初期故障形破壊 が, 放電コンディショニング後は偶発故障形破壊が発生す ると考えられた。また, 真空ギャップでは経年劣化形破壊 
は発生しないと考えられた。

ここで図 4(a)(b)の長時間 E-t 特性は，測定時間範囲内で は単一の直線で表現できる特性となっているが，さらに低 電界で長時間測定すれば, 直線の傾きが途中で変化し屈曲 する可能性もある。その場合の傾きの変化については，経 年劣化形破壊は発生しない点に留意すると, 傾きが屈曲前 よりも大きくなる可能性は小さいと推測される。

\section{4. まとめ}

平等電界および不平等電界分布の真空ギャップに対し長 時間連続で交流電圧を印加し，長時間 E- $\mathrm{t}$ 特性を測定した。 同特性中の垂下係数の值，および同特性に対する放電コン ディショニング効果を検討した。また, 同特性のワイブル プロット処理により算出した形状パラメータ $\mathrm{m}$ の值から, 長期課電による電極表面状態の経時変化の有無を検討し た。これらの真空ギャップ絶縁の長期信頼性に関する検討 から, 以下の結論が得られた。

（1）放電コンディショニング処理後の長時間 $\mathrm{E}-\mathrm{t}$ 特性の 垂下係数 $\mathrm{n}$ は, 平等電界ギャップでは最大 $\mathrm{n}=75$, 不平等電 界ギャップでは最大 $\mathrm{n}=25$ となった。また両ギャップにおけ る最小值は $\mathrm{n}=22$ となった。

（2）放電コンディショニング未実施のギャップの破壊 電界は低く, かつ課電時間に対する依存性は見出せない。 依存性が見出せるようにするには，放電コンディショニン グ処理が必要である。この処理の繰り返しにより長時間 E-t 特性は高電界側にシフトし, 特に平板対平板ギャップでは 垂下係数が増加する。

（3）長時間課電時の破壊モードは, 放電コンディショニ ング未処理では初期故障形, 処理後は偶発故障形である。 電極表面状態の経時変化などによる経年劣化形破壊は生じ ない。

これらの結論は，真空絶縁を利用した開閉装置の長期絶 縁信頼性の向上に有益であると考える。

(平成 14 年 8 月 29 日受付, 平成 15 年 1 月 22 日再受付)

\section{文献}

(1) T. Maruyama, S. Miyamoto, K. Koyama, and S. Sato: "Insulating Rod Operated in a Vacuum Vessel", J. Vacuum Society in Japan, Vol.43, No.1, pp.32-36 (2000) (in Japanese)

丸山稔正・宮本聖一・小山健一・佐藤伸治 :「真空中で使用する絶縁 操作ロッド」, 真空, 43, No.1, pp.32-36 (2000)

(2) T. Shioiri, H. Sasage, M. Miyagawa, K. Yokokura, and I. Oshima: "Improvement of Reliability on Vacuum Disconnecting Switch for Solid Insulated Switchgear", Proc. of 2001 National Convention, IEE Japan, pp.2592-2592 (2001) (in Japanese)

塩入 哲・捧 浩資・宮川 勝・横倉邦夫・大島 嚴：「 $24 \mathrm{kV}$ 固体 絶縁スイッチギア用真空断路器の信頼性向上」, 平成 13 年電気学会 全国大会, 分冊 6, pp.2592-2592 (2001)

(3) S. Kajiwara, T. Tanimizu, M. Tkahashi, and Y. Yotsumoto : "Development of $24 \mathrm{kV}$ Vacuum Switchgear with Multi-Functional Vacuum Interupter", The Papers of Technical Meeting on Switchgear Protection, IEE Japan, SP-98-47 (1998) (in Japanese)

梶原 悟・谷水 徹 - 高橋正行 - 四元善治: 「24kV 配電用集積形ス イッチギアの開発」, 電気学会開閉保護研究会資料, SP-98-47 (1998)

（4）鶴田浩一:「高真空中の絶縁破壊現象」, 放電研究, No.96, pp.14-35 (1983)

(5) H. Fujii and S. Hiro: "Surface Flashover of Dielectrics during Low-Energy Electron Beam Irradiation in Vacuum", T. IEE Japan, Vol.119-A, No.2, pp.177-182 (1999-2) (in Japanese) 藤井治久・廣 三寿: 「電子ビーム照射下の絶縁物の沿面放電特性」, 電学論 A, 119, 2, pp.177-182 (1999-2)

(6) G.A.Mesyats and D.I.Proskurovsky : "Pulsed electrical discharge in vacuum", p.17, Springer Verlag (1989)

（7）「 $\mathrm{SF}_{6}$ ガスの V-t 特性」電気学会技報(II部), No.206, p.15 (1986)

(8) T. Tani, K. Otosaki, S. Isoma, S. Matsuda, and S. Hirabayashi : "Study on the Voltage Endurance and Prediction of the Dielectric Breakdown of High Voltage Rotating Machine Insulations", T. IEE Japan, Vol.105-A, No.7, pp.357-364 (1985-7) (in Japanese) 谷 功 - 乙崎 清 - 磯間信也 - 松田禎夫 - 平林庄司 :「高圧回転器 絶縁の課電劣化特性と絶縁破壞の予知に関する一考察」, 電学論 $\mathrm{A}$, 105, 7, pp.357-364 (1985-7)

（9）「真空中での放電の利用とその抑制」, 電気学会技報, No.586, p.12 (1996)

（10）鳥山四男・堺 孝夫・室岡義広 : 高電圧工学, コロナ社（1980）
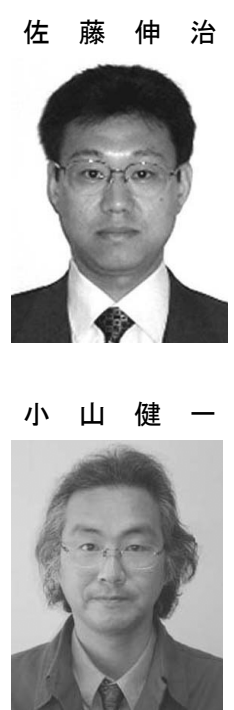

系 谷孝行
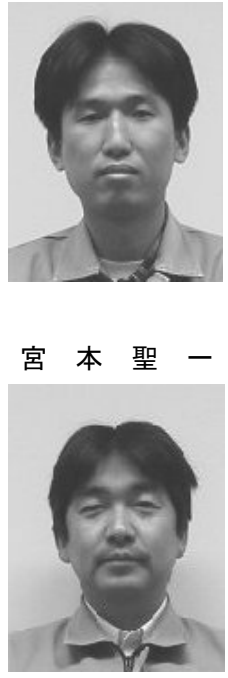

（正員） 1967 年 8 月 2 日生。1992 年 3 月武蔵 工業大学大学院修士課程修了 (電気工学)。同 年 4 月三菱電機 (株) 入社。主として真空絶縁技 術・ガス絶縁技術の研究開発に従事。現在, 先 端技術総合研究所電機システム技術部遮断器 グループ所属。

（正員） 1959 年 6 月 19 日生。1985 年 3 月大阪 大学大学院修士課程修了(電気工学)。同年 4 月 三菱電機 (株) 入社。主として真空遮断器, ガス 絶縁開閉装置における遮断, 絶縁技術の研究開 発に従事。現在, 先端技術総合研究所電機シス テム技術部遮断器グループマネージャ。

（正員） 1970 年 1 月 16 日生。1994 年 3 月徳島 大学大学院修士課程修了 (電機電子工学)。同 年 4 月三菱電機 (株) 入社。主として真空バルブ の開発・設計に従事。現在, 受配電システム 事業所 開閉装置製造部 遮断器設計課所属。

（非会員） 1961 年 2 月 11 日生。1983 年愛媛大 学工学部冶金学科卒業。同年 4 月三菱電機 (株) 入社。主として真空バルブの接点材料開発, 製 造プロセス開発に従事。現在, 受配電システム 事業所 開閉装置製造部 電力管係長。技術士 (金属部門)。日本金属学会, 日本材料科学会 会員。 